\title{
Investigation of Agrresion Levels of the University Ice Hockey Players According to Different Variables
}

\author{
Öner Gülbahçe ${ }^{1}$, Arzu Gülbahçe ${ }^{1}$ \\ ${ }^{1}$ Ataturk University, Kazim Karabekir Faculty of Education, Erzurum/Turkey \\ Correspondence: Öner Gülbahçe, Ataturk University, Kazim Karabekir Faculty of Education, Erzurum / Turkey.
}

Received: February 21, 2019

Accepted: February 28, 2019

Online Published: March 13, 2019

doi:10.11114/jets.v7i3S.4143

URL: https://doi.org/10.11114/jets.v7i3S.4143

\begin{abstract}
This study was conducted in order to investigate aggression levels of the university ice hockey players in the academic year of 2017-2018 according to different variables. The universe of the research consisted of university students and the sample of the research consisted of 91 students, 49 of whom were male and 42 were female, who participated to UNILIG Ice Hockey Championship organized in Erzurum, Turkey on 22 February to 2 March 2018. The Buss-Perry aggression scale, which was adapted to Turkish by Madran (2013), was used to determine aggression levels of the students'. In the analysis of the data, frequency distribution was used to determine the demographic characteristics, the Independent Samples $\mathrm{T}$ test was used to examine the differentiation status between two independent variables and aggression, and the One Way Anova analysis tests were conducted to examine the differentiation status between more than two variables and aggression. All these tests were analyzed in SPSS 21 package program and the significance was evaluated at $\mathrm{p}<0,05$ level. It was found that there was a significant difference between the students' sub-dimensions of aggression and gender, age, weekly training time, and purpose of playing ice hockey.

In sub-dimensions of anger, physical and verbal aggression, it was found that the total score of the male students were higher than the female students. In the sub-dimension of verbal aggression, the total scores of the students younger than 20 years old were lower than the students in 21-24 years old and the students more than 25 years old. In the sub-dimension of verbal aggression, the total scores of students doing 3-5 hours weekly training were lower than the students doing training more than 6 hours a week. In the sub-dimension of physical aggression, the total scores of the students doing sports with purpose of financial benefit were higher than the students doing sports with purpose of social activity and being healthy.
\end{abstract}

In ice hockey, which is a sport where the aggression employs a lot of role and has a direct impact on success, players are advised to take various trainings such as anger control to prevent their aggressive behaviors.

Keywords: sports, aggression, ice hockey

\section{Introduction}

Aggression is a form of behavior that occurs in individuals in different ways. It is very difficult to distinguish it from other behaviors considering the reasons that impinge on aggression. It is because we also encounter aggression as a form of behaviors such destruction, wounding, anger, hatred, as well as various verbal reactions. On the other hand, aggression is a concept that is used to express the situations related to the attitudes involving different reactions (Köksal, 1991). When it is thought that history of humanity is composed of wars, deaths, booty and conquest land, it is clear what level of aggression in person's life takes place. In recent years, it is a well-known fact that there has been a significant increase in aggressive behaviors that end with violence around the world (Korkut, 2002).

One of the reasons that trigger aggression is that things are not going well or being stuck. The aggressive behavior can be characterized as a reaction to the effect of feeling of inhibition. Even though some aggressive behaviors appear in order to annihilate situation that cause inhibition, they sometimes can cause adverse reactions and make the situation worse (Cüceloğlu, 2005). Aggression consists of verbal and symbolic behaviors, which include irritability, competition, frustration, ambition and fear. It aims to harm the others, stop them, prevent their progress or assure the self. Aggression may occur in a peaceful and self-preservative form. It may also occur as a damaging behavior. People around the self may be at the target of aggression, as well as the institutions. If the person has a mental disorder the self can be targeted too (Budak, 2000). Various studies were conducted on the reasons for aggression and different suggestions were 
presented. They may be divided into two groups in general terms. The first group states that aggression is hereditary and sensible while the second group points out environmental factors and learning process. In other words, aggression can be expressed in two different approaches as an innate or acquired motivations (Köknel, 1986).

The sports are also influenced from increase of violence and aggression in society. Nowadays, people increasingly have interest in doing sports and especially sports in certain branches such as ice hockey, football and basketball. And the rapid increase in sponsorship and advertising revenues in parallel with this interest has caused the competitions in these branches to become harder with each passing day. As the competition conditions get harder, the sporting events witness more vicious strives, unethical behaviors, fighting and negative behaviors (Asma, 2008).

We frequently observe aggression in our life and sports also. In our daily lives, aggressive behaviors emerge as a result of the tiredness of working life, financial difficulties and difficulties of ordinary life. However aggressive behaviors sre permitted in sports as they aim to beat the opponent team (Güner, 2006).

Sport is not only a struggle for being the fastest, the strongest, and the most successful, but it is also a game, competition and entertainment with certain principles and rules. The aim of the sport is not only to compete and race with opponents, but is also to support love, peace and brotherhood. Some athletes or fans who disregard, misuse, or ignore these goals make sport the area where violence and aggressive behaviors are displayed (Orphan, 2005).

Aggression in sports can be defined as the fact that one or more of the athletes, coaches or spectators are affected by psychological, social or biological factors, and so try to harm the opponent orally or physically by disregarding the universal principles and rules of the sport. For initiatives aimed at preventing aggression and violence in sport, it is necessary to know the origins of aggression, to take responsibility by coach, athletes and club managers, to avoid media publications that will trigger aggression, and to support to training of spectators, fans and society to act in the framework of fair play (Dervent, 2007). Actually, in almost all of the sports branches, athletes can show aggressive behaviors by using physical force under certain rules. Therefore, the level of aggression in each sport is not same. Some sports, such as American football, ice hockey, boxing and wrestling contain more aggressive elements (Eripek, 1993).

Ice-hockey, which is an Olympic branch and a sport having a lot of aggression and fighting in its nature, was played for the first time by Northern Europeans in the middle ages. It was played in its primitive form in Canada during mid-19th century and a hundred years later it was begun to be played in Turkey. It is considered as "the fastest team game in the world" because it is played on ice. In the ice hockey, which is played very fast and allows body contacts as a result of hard physical interventions, there may be frequent conflicts and scuffs between the players. The athletes who cannot control the tensions after these scuffs and debates can exhibit aggressive behaviors. It is acknowledged that fighting and aggressive behaviors are present in the nature of ice hockey (www.cnnturk.com). In this study, it was aimed to investigate the aggression levels of the students who were playing ice hockey according to different variables.

\section{Method}

\section{Research Model}

This research is a descriptive study of screening model. The model is often used to determine the interaction and quantity between two or more variables. Relational screening model, which does not give a real cause-effect relation, allows estimation of the situation in other variable or variables in accordance with the information of a particular variable (Büyüköztürk, Çakmak, Akgün, Karadeniz and Demirel, 2014).

\section{Working group}

The sample of the research consisted of 91 university students, 49 of whom were male and 42 were female, participated to UNILIGG Ice Hockey Championship organized in Erzurum, Turkey on 22 February to 2 March 2018. The study group was determined by appropriate sampling method.

\section{Data collection tools}

Bussy-perry aggression scale: The Buss Perry aggression scale, which examines the aggressive behaviors of the university students, consists of 5 likert and 29 items. 9 of these items consist of physical aggression subheadings $(13,8,2,11,25,16,29,22,5), 8$ items consist of hostility subheadings $(20,24,3,26,10,15,7,17), 7$ items consist of anger subheadings $(19,28,1,18,9,23,12)$ and 5 items consist of constitute verbal aggression subheadings $(27,6,21,14,4)$. The high scores obtained from the sub-dimensions of the scale indicate that the characteristics of the individual regarding to that dimension are high. The items of the scale, which are prepared in five options of Likert type, are coded as (1) I totally disagree (2) I disagree, (3) I am not sure, (4) I agree, (5) I totally agree. Items 9 and 16 are coded in reverse order.

Socio-demographic information form: The students were given a socio-demographic information form, which includes gender, age, weekly training times and the purpose for doing sports. 


\section{Analysis of data}

In the analysis of the data, frequency distribution was used to determine the demographic characteristics, the Independent Samples $\mathrm{T}$ test was used to examine the differentiation status between two independent variables and aggression, and the One Way Anova analysis tests were conducted to examine the differentiation status between more than two variables and aggression. All these tests were analyzed in SPSS 21 package program and the significance was evaluated at $\mathrm{p}<0,05$ level. It was found that there was a significant difference between the students' sub-levels of aggression and gender, age, weekly training time, and purpose of doing ice hockey.

\section{Results}

Table 1. Gender and Age Distribution of the Students

\begin{tabular}{c|c|c|c|c}
\hline \multicolumn{2}{c|}{ Variable } & $\mathbf{N}$ & \% & Total \% \\
\hline \multirow{4}{*}{ Gender } & Female & 42 & 46,2 & 46,2 \\
\cline { 2 - 5 } & Male & 49 & 53,8 & 100,0 \\
\cline { 2 - 5 } & Total & 91 & 100,0 & \\
\hline \multirow{4}{*}{ Age } & 20 years old and younger & 22 & 24,2 & 24,2 \\
\cline { 2 - 5 } & Between 21-24 years old & 50 & 54,9 & 79,1 \\
\cline { 2 - 5 } & 25 years old and older & 19 & 20,9 & 100,0 \\
\cline { 2 - 5 } & Total & 91 & 100,0 & \\
\hline
\end{tabular}

The research was conducted on a total of 91 ice hockey students, 42 of whom were female and 49 of them were male, and majority was between 21-24 years old.

Table 2. Distribution of Students' Sports Activity Status

\begin{tabular}{c|c|c|c|c}
\hline \multicolumn{2}{c|}{ Variable } & N & \% & Total \% \\
\hline \multirow{3}{*}{$\begin{array}{c}\text { Weekly Training } \\
\text { Time }\end{array}$} & 2 hours or less & 15 & 16,5 & 16,5 \\
\cline { 2 - 4 } & Between 3-5 hours & 32 & 35,2 & 51,6 \\
\cline { 2 - 4 } & 6 hours or more & 44 & 48,4 & 100,0 \\
\cline { 2 - 4 } & Total & 91 & 100,0 & \\
\hline \multirow{3}{*}{$\begin{array}{c}\text { Purpose of Doing } \\
\text { the Sports Branch }\end{array}$} & Being Healthy & 16 & 17,6 & 17,6 \\
\cline { 2 - 4 } & Financial Benefit & 17 & 18,7 & 36,3 \\
\cline { 2 - 4 } & Social Activity & 58 & 63,7 & 100,0 \\
\cline { 2 - 4 } & Total & 91 & 100,0 & \\
\hline
\end{tabular}

Considering ice hockey training period and the purpose for playing ice hockey, it was observed that they were playing it mostly 6 hours or more a week and were playing it mostly as a social activity.

Table 3. Averages Scores of Female and Male Students Obtained from the Aggression Sub-Scales and t Value of Differences between the Averages and Standard Deviations

\begin{tabular}{|c|c|c|c|c|c|c|}
\hline Aggression sub-dimensions & Gender & $\mathbf{N}$ & $\mathbf{X}$ & Ss & $\mathbf{T}$ & $\mathbf{p}$ \\
\hline \multirow{2}{*}{ Physical Aggression } & Female & 42 & 21,8571 & 6,21396 & $-3,097$ & \multirow{2}{*}{, $002 *$} \\
\hline & Male & 49 & 26,3878 & 7,53275 & $-3,143$ & \\
\hline \multirow{2}{*}{ Hostility } & Female & 42 & 21,0952 & 6,70205 & $-1,159$ & \multirow{2}{*}{, 250} \\
\hline & Male & 49 & 22,6327 & 5,95012 & $-1,148$ & \\
\hline \multirow{2}{*}{ Anger } & Female & 42 & 19,2619 & 4,65419 & $-2,460$ & \multirow[b]{2}{*}{, $015^{*}$} \\
\hline & Male & 49 & 21,8776 & 5,37600 & $-2,488$ & \\
\hline \multirow{2}{*}{ Verbal Aggression } & Female & 42 & 15,0952 & 3,86863 & $-2,423$ & \multirow{2}{*}{, $017 *$} \\
\hline & Male & 49 & 17,0408 & 3,77469 & $-2,419$ & \\
\hline
\end{tabular}

Considering the total scores obtained from the aggression subscales of the female and male ice hockey players, a difference was found in physical aggression, anger and verbal aggression sub-dimensions in $\mathrm{P}<0,05$ significance level. It was observed that the male players have higher total scores than females in physical, anger and verbal aggression sub-dimensions. No significant difference was found in hostility sub-dimension. 
Table 4. Averages Scores of the Students obtained from Age and Aggression Sub-Scales and Values of Differences between the Averages and Standard Deviations

\begin{tabular}{|c|c|c|c|c|c|c|c|}
\hline $\begin{array}{c}\text { Aggression } \\
\text { sub-dimensions }\end{array}$ & Age & $\mathbf{N}$ & $\mathbf{X}$ & Ss & $\mathbf{F}$ & $\mathbf{P}$ & Difference \\
\hline \multirow{4}{*}{$\begin{array}{l}\text { Physical } \\
\text { Aggression }\end{array}$} & 20 years old and younger & 22 & 23,2273 & 8,47928 & \multirow{4}{*}{,674 } & \multirow{4}{*}{,319 } & \multirow{4}{*}{$\cdots \cdots$} \\
\hline & Between 21-24 years old & 50 & 25,1000 & 6,78308 & & & \\
\hline & 25 years old and older & 19 & 23,4211 & 7,20583 & & & \\
\hline & Total & 91 & 24,2967 & 7,28086 & & & \\
\hline \multirow{4}{*}{ Hostility } & 20 years old and younger & 22 & 21,3182 & 7,61194 & \multirow{4}{*}{,287 } & \multirow{4}{*}{,516 } & \multirow{4}{*}{$\ldots \ldots \ldots$} \\
\hline & Between 21-24 years old & 50 & 22,3800 & 6,03693 & & & \\
\hline & 25 years old and older & 19 & 21,4211 & 5,62056 & & & \\
\hline & Total & 91 & 21,9231 & 6,31969 & & & \\
\hline \multirow{4}{*}{ Anger } & 20 years old and younger & 22 & 19,6364 & 5,07605 & \multirow{4}{*}{ 635 } & \multirow{4}{*}{,263 } & \multirow{4}{*}{$\ldots \ldots \cdots$} \\
\hline & Between 21-24 years old & 50 & 21,1400 & 5,29925 & & & \\
\hline & 25 years old and older & 19 & 20,6316 & 5,15548 & & & \\
\hline & Total & 91 & 20,6703 & 5,19627 & & & \\
\hline \multirow{4}{*}{$\begin{array}{c}\text { Verbal } \\
\text { Aggression }\end{array}$} & 20 years old and younger & 22 & 14,5000 & 3,72572 & \multirow{4}{*}{2,868} & \multirow{4}{*}{,030 } & \multirow{4}{*}{$1<2,3$} \\
\hline & Between 21-24 years old & 50 & 16,4800 & 3,80783 & & & \\
\hline & 25 years old and older & 19 & 17,1579 & 4,05878 & & & \\
\hline & Total & 91 & 16,1429 & 3,92024 & & & \\
\hline
\end{tabular}

Considering the total scores obtained from the aggression subscales of the students in different age groups, a difference was found in verbal aggression sub-dimension in $\mathrm{P}<0.05$ significance level. In the verbal aggression sub-dimension, it was observed that the students who were 20 years of old and younger have lower total scores than the students between the 21-24 years old and above 25 years old. There was no significant difference in physical aggression, hostility and anger sub-dimensions though.

Table 5. Averages Scores of the students obtained from Weekly Training Times and Aggression Sub-Scales and Values of Differences between the Averages and Standard Deviations

\begin{tabular}{|c|c|c|c|c|c|c|c|}
\hline $\begin{array}{c}\text { Aggression } \\
\text { sub-dimensions }\end{array}$ & Time & $\mathbf{N}$ & $\mathbf{X}$ & Ss & $\mathbf{F}$ & $\mathbf{P}$ & Difference \\
\hline \multirow{4}{*}{$\begin{array}{l}\text { Physical } \\
\text { Aggression }\end{array}$} & 2 hours or less & 15 & 24,2667 & 5,59932 & \multirow{4}{*}{1,427} & \multirow{4}{*}{,246 } & \multirow{4}{*}{$\ldots \ldots$} \\
\hline & Between 3-5 hours & 32 & 22,6563 & 6,39359 & & & \\
\hline & 6 hours or above & 44 & 25,5000 & 8,23351 & & & \\
\hline & Total & 91 & 24,2967 & 7,28086 & & & \\
\hline \multirow{4}{*}{ Hostility } & 2 hours or less & 15 & 23,2667 & 8,27618 & \multirow{4}{*}{,444 } & \multirow{4}{*}{ 643 } & \multirow{4}{*}{........ } \\
\hline & Between 3-5 hours & 32 & 21,4063 & 5,90166 & & & \\
\hline & 6 hours or above & 44 & 21,8409 & 5,94527 & & & \\
\hline & Total & 91 & 21,9231 & 6,31969 & & & \\
\hline \multirow{4}{*}{ Anger } & 2 hours or less & 15 & 20,8667 & 5,50151 & \multirow{4}{*}{1,569} & \multirow{4}{*}{, 214} & \multirow{4}{*}{ …..... } \\
\hline & Between 3-5 hours & 32 & 19,4063 & 4,57101 & & & \\
\hline & 6 hours or above & 44 & 21,5227 & 5,44524 & & & \\
\hline & Total & 91 & 20,6703 & 5,19627 & & & \\
\hline \multirow{4}{*}{$\begin{array}{c}\text { Verbal } \\
\text { Aggression }\end{array}$} & 2 hours or less & 15 & 15,0667 & 3,89994 & \multirow{4}{*}{3,288} & \multirow{4}{*}{,026 } & \multirow{4}{*}{$2<3$} \\
\hline & Between 3-5 hours & 32 & 15,1875 & 2,97774 & & & \\
\hline & 6 hours or above & 44 & 17,2045 & 4,31104 & & & \\
\hline & Total & 91 & 16,1429 & 3,92024 & & & \\
\hline
\end{tabular}

Considering the total scores obtained from aggression and weekly training time subscales, a difference was found in verbal aggression sub-dimension in $\mathrm{P}<0.05$ significance level. In the verbal aggression sub-dimension, it was observed that the total scores of the students who were doing training between 3-5 hours a week were lower than the students who were doing weekly training 6 hours or more. There was no significant difference in physical aggression, hostility and anger sub-dimensions though. 
Table 6. Averages Scores of the Students Obtained from Purpose of Playing Ice Hockey and Aggression Sub-Scales and Values of Differences between the Averages and Standard Deviations

\begin{tabular}{|c|c|c|c|c|c|c|c|}
\hline $\begin{array}{c}\text { Aggression } \\
\text { sub-dimensions }\end{array}$ & Purpose & $\mathbf{N}$ & $\mathbf{X}$ & Ss & $\mathbf{F}$ & $\mathbf{P}$ & Difference \\
\hline \multirow{4}{*}{$\begin{array}{l}\text { Physical } \\
\text { Aggression }\end{array}$} & Being Healthy & 16 & 24,3750 & 6,76141 & \multirow{4}{*}{3,530} & \multirow{4}{*}{,009 } & \multirow{4}{*}{$2>3$} \\
\hline & Financial Benefit & 17 & 28,2941 & 7,22638 & & & \\
\hline & Social Activity & 58 & 23,1034 & 7,12714 & & & \\
\hline & Total & 91 & 24,2967 & 7,28086 & & & \\
\hline \multirow{4}{*}{ Hostility } & Being Healthy & 16 & 22,5000 & 7,43864 & \multirow{4}{*}{, 107 } & \multirow{4}{*}{,899 } & \\
\hline & Financial Benefit & 17 & 22,1176 & 5,67761 & & & \\
\hline & Social Activity & 58 & 21,7069 & 6,26886 & & & \\
\hline & Total & 91 & 21,9231 & 6,31969 & & & \\
\hline \multirow{4}{*}{ Anger } & Being Healthy & 16 & 20,4375 & 5,58532 & \multirow{4}{*}{1,029} & \multirow{4}{*}{,362 } & \\
\hline & Financial Benefit & 17 & 22,2941 & 5,45166 & & & \\
\hline & Social Activity & 58 & 20,2586 & 5,01073 & & & \\
\hline & Total & 91 & 20,6703 & 5,19627 & & & \\
\hline \multirow{4}{*}{$\begin{array}{c}\text { Verbal } \\
\text { Aggression }\end{array}$} & Being Healthy & 16 & 14,1250 & 3,84491 & \multirow{4}{*}{4,325} & \multirow{4}{*}{,004 } & \multirow{4}{*}{$2>1$} \\
\hline & Financial Benefit & 17 & 18,0000 & 3,93700 & & & \\
\hline & Social Activity & 58 & 16,1552 & 3,72192 & & & \\
\hline & Total & 91 & 16,1429 & 3,92024 & & & \\
\hline
\end{tabular}

Considering the total scores obtained from aggression and purpose of playing ice hockey subscales, a difference was found in physical and verbal aggression sub-dimension in $\mathrm{P}<0,05$ significance level. In the physical aggression sub-dimension it was observed that, the total scores of the students who were playing ice hockey for financial benefit were higher than the students who were playing ice hockey as a social activity. Moreover, in the verbal aggression sub-dimension, the total scores of the students who were playing ice hockey for financial benefit were higher than the students who were playing ice hockey for being healthy. There was no significant difference in hostility and anger sub-dimensions.

\section{Discussion and Conclusion}

In the study, it was found that the male students have higher physical, anger and verbal aggression sub-dimension levels than the female students. Similarly, in his study Scharf (2000) found that there was a significant difference between gender and verbal and physical aggressions, and males practiced verbal and physical aggressions more often than females. In their studies conducted on aggression and genders of the adolescents Giles and Heyman (2005) concluded that males' aggression levels were higher than females. These studies have parallel results with the findings of this study.

In the verbal aggression sub-dimension, it was determined that the total score of the students who were 20 years old and younger were lower than the students between 21-24 years old and 25 years old or older. Bahadır and Erdoğan (2016) also found that students in 24-26 years age groups at the department of physical education and sports have higher aggression levels than students in 18-20 age groups.

In his study conducted on aggression levels of the students at high school elite ice hockey players Kurudirek (2014) found that 15 years old athletes showed less aggression than athletes between 16 and 17 years old. The results of these studies are in parallel with the findings of this research in terms of age variable. In another study, no statistically significant difference was found in the aggression scores of the student sportsmen between 11-13 years of age (Bostanc1 et al., 2017).

In the verbal aggression sub-dimension, a significant difference was found between aggression and weekly ice hockey training time sub-dimensions. It was determined that, in the verbal aggression sub-dimension, the total scores of the students who were doing training between 3-5 hours a week were lower than the students who were doing training 6 hours or more in a week. Yurttaş (2016) investigated aggression level of university students who were doing sports and not doing sports. And he found that in the physical aggression, anger, verbal aggression subscales, the students who were doing sports more than 6 hours a week have higher average scores than the students who were doing sports 2 hours or less.

In the physical aggression sub-dimension, it was observed that the total scores of the students who were doing sports for financial benefit were higher than the students who were doing sports as a social activity. Moreover, in the verbal aggression sub-dimension, the total scores of the students who were doing sports for financial benefit were higher than the students who were doing sports for being healthy. Özdevecioğlu and Yalçın (2010) explained financial benefit, wages and job guarantee as external satisfactions in sports. And they reported that athletes with low external satisfactions have more aggressive behaviors. This result is also in parallel with our finding that the students who were doing sports for financial benefit have a high aggression level.

Nowadays, in some sports branches, violence and aggression are experienced intensively among athletes and spectators in the tribunes even though sports, as a universal fact, bring people together regardless of language, religion and race. Both athletes and spectators need to be informed about this fact in order to eliminate aggressive behaviors exhibited in 
team sports such as ice hockey and in individual sports. So, increasing the hours of physical education and sports courses in schools and providing different sports activities to the students can contribute to reducing young people's aggressive behaviors. Although aggression is inherent in ice hockey, the players can be informed about individual or social negative consequences of aggressive behaviors. In addition, experts can give seminars, organize conferences and give anger control trainings, which would be helpful. Last but not least, educational publications should be made to reduce news about violence and aggression in sports.

\section{References}

Asma, M. (2008). Investigating the Perception of Aggression of Students Participated in Inter-School Competitions in terms of Social-Cognitive Learning Theory (Case of Ankara). Gazi University, Institute of Educational Sciences, Department of Physical Education and Sports Teaching, (Unpublished Master's Thesis).

Bahadır, Z., \& Erdoğan, Ç. H. (2016). Investigation of Aggression Levels of Physical Education and Sports College Students. International Journal of Educational Sciences, 3(7), 33-48

Bostancı, Ö., Oda, B., Şebin, K., \& Erail, S. (2017). Investigation of Optimism and Aggression Levels of 11-13 Years Old Students According to Their Sports Activity Status. Atatürk University Journal of Physical Education and Sports Sciences Volume: 19, Number: 4, December.

Budak S. (2000). Dictionary of Psychology. Ankara: Science and Art Publications.

Büyüköztürk, Ş., Çakmak, E., Akgün, Ö., Karadeniz, Ş., \& Demirel, F. (2014). Scientific research methods. Ankara: PegemA Publications

Cüceloğlu, D. (2005) .Human and Behavior. Istanbul: Remzi Bookstore

Dervent, F. (2007). Aggression Levels of High School Students and Its Relationship to Participating in Sports Activities. Gazi University Institute of Educational Sciences / Department of Physical Education and Sports Teaching, Master's Thesis. Ankara.

Eripek, S. (1993). Sports psychology. Eskişehir Anadolu University Publications, 2(1), 9-15.

Giles, J., \& Heyman, G. D. (2005). Young Children's Beliefs About The Relationship Between Gender and Aggressive Behavior. Child Development. January/February, 76(1), 107-112. https://doi.org/10.1111/j.1467-8624.2005.00833.x

Güner, B. Ç. (2006). Examining aggression levels of athletes engaged in team sports and individual sports. Ondokuz Mayis University, Institute of Health Sciences, Department of Physical Education and Sports.

Köknel, Ö. (1986). Personality From Anxiety to Happiness. İstanbul: Golden Books Publishing House.

Köksal, F. (1991). Relationships between control focus and aggressive behavior. Unpublished PhD Thesis, Ataturk University, Erzurum, Turkey.

Korkut, F. (2002). A preliminary study on the adaptation of the Turkish version of the expressionist aggression scale (EAS). Cukurova University Journal of Educational Sciences, 2(23), 48-53.

Kurudirek, M. İ. (2014). Investigation of Aggression Levels of Elite Ice Hockey Players at High School Level. Gazi University Institute of Health Sciences. Physical Education and Sports Department Sports and Health Sciences Program. Master's Thesis. Ankara.

Özdevecioğlu, M., \& Yalçın, Y. (2010). The Effect of Sports Satisfaction on the Stress and Aggression Levels of Athletes. Niğde University Journal of Physical Education and Sports Sciences, 4(1), 63-76.

Scharf, S. C. (2000). Gender Differences in Adolescent Aggression: an Analysis of Instrumentality vs. Expressiveness, Unpublished Doctoral Thesis Michigan University Dep. of Clinical Psyc., Michigan.

www.cnnturk.com./spor/buz-hokeyi-hakkinda-bilinmesi-gereken-her-sey. Accessed on: 08.04.2016

Yetim, A. (2005). Sociology and Sports. 3. Edition. Istanbul: Morpa Cultural Publications.

Yurttaş, H. (2016). Investigation of Aggression Levels of University Students Who Do Sports and Not. Master's Thesis, Ataturk University Institute of Educational Sciences, Erzurum.

\section{Copyrights}

Copyright for this article is retained by the author(s), with first publication rights granted to the journal.

This is an open-access article distributed under the terms and conditions of the Creative Commons Attribution license which permits unrestricted use, distribution, and reproduction in any medium, provided the original work is properly cited. 